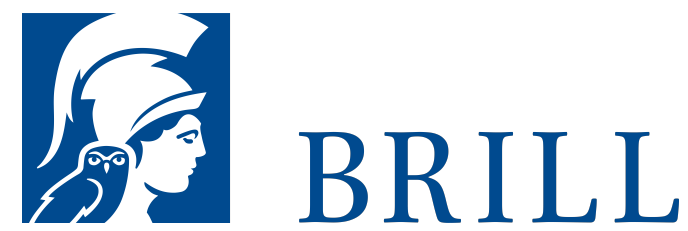

\title{
Die Argonauten und Äneas in Amerika
}

Kommentierte Neuedition des Kolumbusepos Atlantis retecta von Vincentius Placcius und Editio princeps, Übersetzung und Kommentar der Cortesias von P. Petrus Paladinus SJ

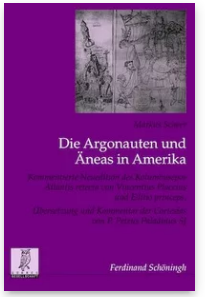

\section{Author: Markus Scheer}

Die Erstausgabe des ältesten lateinischen Epos über Cortés beruht auf dem glücklichen Fund in einer spanischen Sammelhandschrift. Mit rund 1000 Versen hat es etwa denselben Umfang wie das zeitgenössische Kolumbusepos, dessen erste Fassung von 1659 erstmals im Apparat geboten wird. Similien-apparat und Kommentar belegen, wie der spanische Jesuitenpater und der Abiturient des Hamburger Akademischen Gymnasiums antike Epik rezipieren. Die Kolumbusfahrt zur Entdeckung der seit Platon mythenumwobenen Insel Atlantis ist ein Spiegelbild der ÄneasFahrt von Troja nach Latium und der Argonautenfahrt von Griechenland nach Kolchis, wo es das Goldene Vlies zu gewinnen gilt. Außer Valerius Flaccus stiften auch andere kaiserzeitliche und spät-antike Epiker, besonders Claudian, strukturelle Bezugspunkte. Arma virumque cano - das Cortésepos beginnt wie die Äneis. Wie Äneas tritt Cortés auf einer Irrfahrt in die Handlung ein. Er wird auf Kuba vom Statthalter Velázquez gastlich aufgenommen. Der Schutzengel Mexikos durchkreuzt ein für die Befreiung der Azteken von ihrem teuflischen Götzenkult bedrohliches Komplott der Furien und treibt Cortés' Kriegsflotte durch einen Sturm an die Küste Mexikos. Von religiösem und national-spanischem Sendungsbewusstsein geleitet, werden auch Ursprungsmythen der Azteken, ferner die heroisierende Cortésbiographie von López de Gómara verarbeitet.

Pages: 419

Seiten

Language:

German

Subjects:

General,

Literature and

Cultural Studies

Publisher: Brill |

Schöningh

Series:

Studien zur

Geschichte und

Kultur des

Altertums,

Volume: 27

E-Book (PDF)

Released online: 3o Dec 2019

ISBN: 978-3-

657-75636-о

List price

USD $\$ 84.00$

Paperback

Publication date: o5 Oct 2007

ISBN: 978-35०6-75636-7 List price USD. $\$ 84.00$ 
For more information see brill.com

Order information: Order online at brill.com +44330 333 0049 | customerservices@brill.com Submission information: brill.com/authors

Titles published by Brill | Fink, Brill | mentis or Brill | Schöningh: +49(o)715413279216| brill@brocom.de 